\title{
REGULAÇÃO CONSENSUAL: \\ A EXPERIÊNCIA DAS AGÊNCIAS REGULADORAS DE INFRAESTRUTURA COM TERMOS DE AJUSTAMENTO DE CONDUTA
}

\author{
CARLOS EMMANUEL JOPPERT RAGAZZO ${ }^{\dagger}$ \\ GUILHERME DE JESUS FRANCE ${ }^{\dagger \dagger}$ \\ Mariana TAVARES DE CARVALHO VIANNA ${ }^{\dagger \dagger}$
}

\section{UM DOSSIÊ SOBRE ESTADO ADMINISTRATIVO}

PalaVRAS-Chave: Agências Reguladoras; Termos de Ajustamento de Conduta; CADE; Multas Administrativas.

KEYWORDS: Regulatory Agencies; Conduct Adjustment Commitments; CADE; Administrative Fines.

\footnotetext{
† Professor da FGV Direito Rio, Mestre e Doutor em Direito da Cidade pela Universidade do Estado do Rio de Janeiro e LLM em Direito da Concorrência e Regulação de Mercados pela New York University.

† Pesquisador do Centro de Justiça e Sociedade da FGV Direito Rio, Mestre em Direito Internacional pela Universidade do Estado do Rio de Janeiro.

it Pesquisadora do Centro de Pesquisa em Direito e Economia da FGV Direito Rio, Mestranda em Direito Público pela Universidade do Estado do Rio de Janeiro.
} 


\section{SUMÁRIO:}

I. INTRODUÇ̃̃ 0 ..........................................................................................91

II. ADMINISTRAÇÃ̃ CONSENSUAL ...............................................................95

III. Pioneirismo:

o CONSELHO AdMINISTRATIVo de DEFESA ECONÔMICA .................96

IV. TACS NAS AGÊNCIAS REGULADORAS FEDERAIS

DE INFRAESTRUTURA ................................................................................100

1. Agência Nacional de Transportes Terrestres .......................102

2. Agência Nacional de Transportes Aquaviários.....................104

3. Agência Nacional de Aviação Civil.........................................106

4. Agência Nacional de Telecomunicações..................................108

5. Agência Nacional de Energia Elétrica.....................................111

6. Agência Nacional de Águas .....................................................114

7. Agência Nacional do Petróleo, Gás Natural

e Biocombustível ............................................................................115

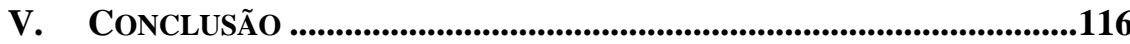

VI. REFERÊNCIAS..............................................................................119

\section{TABLE OF CONTENTS:}

I. INTRODUCTION .......................................................................................91

II. CONSENSUAL AdMINISTRATION ..............................................................95

III. Pioneering:

THE ADMINISTRATIVE COUNCIL OF ECONOMIC DEFENDE ................96

IV. TACS IN THE FEDERAL AGENCIES

FOR INFRASTRUCTURE REGULATION ................................................100

1. National Agencie of Ground Transport................................102

2. National Agencie of Water Transport.....................................104

3. National Agencie of Civil Aviation .........................................106

4. National Agencie of Telecommunications...............................108

5. National Agencie of Electricity ...............................................111

6. National Agencie of Water .......................................................114

7. National Agencie of Oil, Natural Gas, and Biofuels............115

V. CONCLUSION ...................................................................................116

VI. REFERENCES ............................................................................................119 


\section{INTRODUÇÃO}

O processo sancionador no âmbito da regulação econômica vem sofrendo influxo de uma perspectiva mais instrumental, focada na eficiência e aberta às influências do consensualismo. Isso se manifesta pela preterição desse processo e da consequente aplicação de sanções em favor de compromissos, por parte dos atores regulados, de reparação de danos, alteração de comportamentos ou medidas compensatórias que tragam benefícios à sociedade e contribuam para a consecução dos objetivos de política pública. ${ }^{1} \mathrm{Um}$ dos instrumentos por meio do qual esses compromissos são extraídos é o Termo de Ajustamento de Compromisso.

Guia essa transformação uma percepção de que o modelo sancionatório baseado, principalmente, na aplicação de multas não é eficiente. Em esforços de avaliação desse modelo, o Tribunal de Contas da União vem realizando análises periódicas sobre as arrecadações de multas administrativas constituídas por agências reguladoras e outras entidades públicas. ${ }^{2}$ Baixos índices de arrecadação representam um problema permanente - os índices médios de arrecadação de multas, entre 2005 e 2013, nunca ultrapassaram 11\% das multas constituídas. Reconhece-se que não é um problema exclusivo das agências reguladoras - o próprio TCU e o Banco Central, por exemplo, também sofrem com esse problema. As graves consequências são resumidas pelo TCU: (i) multas aplicadas acabam não recolhidas, representando um montante muito significativo, na ordem de $\mathrm{R} \$ 24,9$ bilhões em cinco anos; (ii) impacto direto na redução da eficácia da política, já que o instrumento sancionador acaba não operando o efeito pretendido para manutenção do objetivo regulatório definido na política, por ausência de eficácia. ${ }^{3}$

O que fica claro, portanto, é a necessidade de se repensar esse modelo sancionatório e pretende-se fazê-lo com um enfoque especial no caso das agências reguladoras de infraestrutura. A apresentação de alternativa, consubstanciada nos Termos de Ajustamento de Conduta, serve de linhaguia a partir da qual essa reavaliação será realizada. Essas agências demonstraram graves déficits na capacidade de efetivamente arrecadar

${ }^{1}$ MARQUES NETO, Floriano de Azevedo; CYMBALISTA, Tatiana Matiello. Os Acordos Substitutivos do Procedimento Sancionatório e da Sanção. Revista Brasileira de Direito Público - RBDP, Vol. 8, 31, 2010, p. 3.

2 Para as informações relativas ao período entre 2005 e 2009, cf. Relatório de Levantamento de Auditoria TC 022.631/2009-0.

3 Para as informações relativas ao período entre 2005 e 2009, cf. Relatório de Levantamento de Auditoria TC 022.631/2009-0. 
as multas constituídas, como fica claro pelo gráfico abaixo. No período entre 2009 e 2013, nenhuma das agências reguladoras na área de infraestrutura foi capaz de arrecadar nem sequer metade dos montantes de multas constituídas.

\section{Gráfico 1:}

Percentual dos valores de multas aplicadas efetivamente arrecadas (2009-2013)

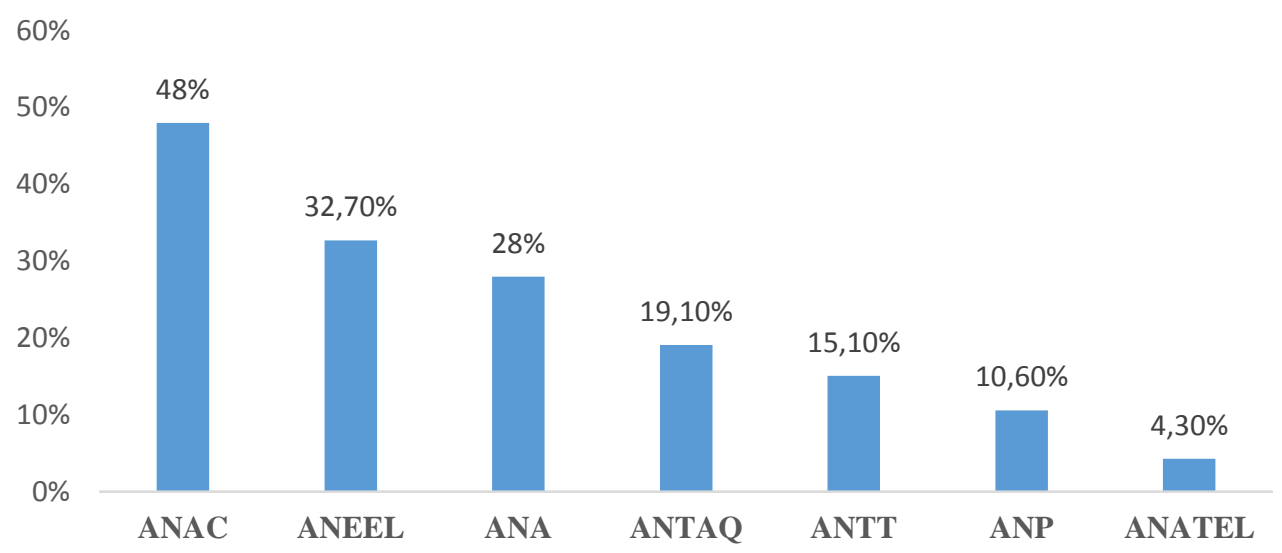

Fonte: TCU. ${ }^{4}$

Os TACs têm três características principais: (i) a consensualidade, (ii) a alternatividade, já que suspende e substitui o processo administrativo e (iii) a finalidade pública. ${ }^{5}$ É esta primeira característica que demanda uma análise mais detida desse novo momento do Direito Administrativo. A emergência da consensualidade se dá em resposta a movimentos reformadores e modernizadores de Estado, que procuram uma Administração mais eficiente e voltada para o resultado. A Administração Pública consensual é um caminho que prega uma postura

${ }^{4}$ TRIBUNAL DE CONTAS DA UNIÃO. Relatório e Parecer Prévio sobre as Contas do Governo da República - Exercício 2013, p. 95. Disponível em:

$<$ http://portal.tcu.gov.br/tcu/paginas/contas governo/contas 2013/docs/Relat\%C3\%B3r io.pdf $>$. Acesso em: 17 de julho de 2017.

${ }^{5}$ SADDY, André; GRECO, Rodrigo. Termo de Ajustamento de Conduta em Procedimentos Sancionatórios Regulatórios. Revista de Informação Legislativa, Vol. 52, 206, 2015, p. 171. 
mais dialógica entre administradores e administrados ${ }^{6}$, havendo uma inclusão da participação popular nas decisões administrativas, em oposição à atuação administrativa impositiva e unilateral.

A atuação administrativa consensual não passou despercebida pelo Direito Administrativo brasileiro; em especial, após a reforma do Estado o tema da consensualidade passou a ser debatido pelos juristas brasileiros. De fato, crescem os números de artigos acadêmicos voltados ao estudo da consensualidade ${ }^{7}$, normas passam a prever instrumentos consensuais ${ }^{8} \mathrm{e}$, na prática, entes públicos já aplicam meios consensuais e obtêm importantes resultados em termos de eficiência.

Independente disso, os acordos são possibilidades ainda incipientes na maioria das agências reguladoras de infraestrutura no Brasil. Por isso, o objetivo do presente artigo é discutir a importância da utilização de acordos administrativos para substituir os processos administrativos

${ }^{6}$ Refere-se à figura de um Estado "que conduz sua ação pública segundo outros princípios, favorecendo o diálogo da sociedade consigo mesma". BELLOUBET-FRIER, Nicole; TIMSIT, Gérard. L'administration en Chantiers. Revue du Droit Public et de la Science Politique en France et a l'Étranger, Paris, No. 2, 1994, p. 314'.

${ }^{7}$ A título exemplificativo pode-se citar: ALMEIDA, Fernando Dias Menezes de. Mecanismos de Consenso no Direito Administrativo. In: Alexandre Santos de Aragão; Floriano de Azevedo Marques Neto. (Orgs.). Direito Administrativo e seus Novos Paradigmas. Belo Horizonte, MG: Editora Fórum, 2008; MOREIRA NETO, Diogo de Figueiredo. Novos Institutos Consensuais da Ação Administrativa. Revista de Direito Administrativo, No. 231, 2003; MOREIRA NETO, Diogo de Figueiredo. Novas Tendências da Democracia: Consenso e Direito Público na virada do Século - o caso brasileiro. Revista Eletrônica sobre a reforma do Estado, No. 13, 2008; MARQUES NETO, Floriano de Azevedo; CYMBALISTA, Tatiana Matiello. Os Acordos Substitutivos do Procedimento Sancionatório e da Sanção. Revista Brasileira de Direito Público - RBDP, Vol. 8, 31, 2010; DALLARI, Adílson. Viabilidade da Transação entre o Poder Público e o Particular. Interesse Público, Vol. 4, 13, 2002; ARAGÃO, Alexandre. A Consensualidade no Direito Administrativo: Acordos Regulatórios e Contratos Administrativos. Revista de Informação Legislativa, Vol. 42, 167, 2005; SADDY, André; GRECO, Rodrigo. Termo de Ajustamento de Conduta em Procedimentos Sancionatórios Regulatórios. Revista de Informação Legislativa, Vol. 52, 206, 2015; e SUNDFELD, Carlos Ari; CÂMARA, Jacinto. Acordos Substitutivos nas Sanções Regulatórias. Revista de Direito Público da Economia - RDPE, Vol. 9, 34, 2011.

8 Sem a pretensão de esgotar, podemos citar: o artigo 29 da Lei 9.656/98 (Lei da ANS); o artigo 5º da Lei 7.347/85 (Lei da Ação Civil Pública) e o artigo 4º-A da Lei 9.469/97 (Lei da AGU). 
sancionadores, uma vez que se mostram mecanismo jurídico disponível e eficiente no combate à judicialização excessiva, representando forte sinalização de redução de risco regulatório e fazendo com que o modelo regulatório se torne mais atrativo para o setor privado para fins de investimento.

Se são incipientes nas agências em comento, no Conselho Administrativo de Defesa Econômica (CADE) esses acordos já se tornaram parte consolidada da política de proteção à livre concorrência. Essa é a origem da decisão de se discutir o histórico de desenvolvimento normativo que permite a celebração desses acordos no CADE, com especial foco nos seguintes elementos: (i) quem pode propor e celebrá-los; (ii) quais são os requisitos para a celebração; (iii) qual o procedimento; (iv) quais os efeitos dos acordos; e (v) o quanto são efetivamente aplicados.

Pretende-se, a partir dessa análise, realizar um estudo comparativo entre os instrumentos de acordo nas agências reguladoras de infraestrutura e o modelo tido como referencial do CADE, levando estes mesmos elementos, na medida do possível, em consideração. Isso permitirá diagnosticar os elementos presentes neste e ausentes naquelas, responsáveis, argumenta-se, pela grande diferença no sucesso da aplicação desse instrumento de política regulatória.

O presente artigo está organizado da seguinte maneira: inicialmente, serão apresentadas algumas considerações sobre a emergência do consensualismo na Administração Pública; em seguida, será apresentado o exemplo pioneiro do CADE na celebração de TCCs, cujas lições podem servir de parâmetro para o desenvolvimento de um caminho a ser seguido pelas agências reguladoras; por fim será realizado um estudo de casos comparativo da prática de celebração de TACs pelas agências reguladoras federais de infraestrutura..$^{9}$ Por fim, são sugeridas algumas conclusões preliminares e caminhos promissores para futuras pesquisas.

\footnotetext{
${ }^{9}$ Uma nota sobre terminologia é necessária. Existem algumas variantes empregadas pelos diversos órgãos públicos que serão estudados - Termo de Compromisso de Ajustamento de Conduta (ANATEL), Termo de Ajustamento de Conduta (ANAC), Termo de Ajuste de Conduta (ANTT e ANTAQ), Termo de Compromisso de Ajuste de Conduta (ANEEL). Todos serão referidos igualmente como TAC, para facilitar a compreensão e a leitura do texto.
} 


\section{AdMinistração CONSENSUAL}

A consensualidade é o emprego em larga escala de métodos e técnicas negociais ou contratualizadas no campo das atividades perpetradas pelos órgãos e entidades públicas. O processo de negociação entre as partes é a etapa principal para angariar resultados significativos a partir da substituição do modelo decisório. A negociação possibilita que os agentes privados participem do processo decisório e, consequentemente, há maiores chances de cumprimento dos termos pelo ator privado em comparação à imposição realizada no processo sancionador. Outra vantagem está na diminuição da assimetria informacional existente entre as partes, pois ambas discutem o escopo do acordo, o que resulta em um incremento da confiança. Em alguns setores regulados, a negociação pode representar um mecanismo para ordenar a alocação de recursos. Por fim, os custos administrativos - recursos materiais e humanos despendidos em investigações e processos administrativos - se reduzem já que reuniões e discussões sobre os acordos substitutivos tendem a encurtar procedimentos..$^{10}$

Contudo, os benefícios acima descritos só poderão ser gozados se as agências reguladoras adotarem o mecanismo consensual em maior escala e se estabelecerem políticas regulatórias claras e objetivas. Em particular, a doutrina identifica que o sucesso da política regulatória está em regulações que estabeleçam as condições mínimas, de forma clara e objetiva, da celebração dos acordos com o intuito de facilitar o raciocínio dos agentes regulados, tornando mais fácil a explicação da sua motivação aos acionistas, responsabilidade a que estão sujeitos os administradores das empresas reguladas. ${ }^{11}$

${ }^{10}$ Existe um efeito negativo dos acordos substitutivos no processo decisório, que seria a possibilidade de precificação da condenação. As partes já internalizariam o preço da sanção quando do descumprimento de norma e, por se tratar de um acordo, o preço sancionatório seria menor do que a sanção no processo sancionador comum. POPPER, Andrew. An Administrative Law Perspective on Consensual Decisionmaking.

Administrative Law Review, v. 35, 3, 1983, p. 255.

${ }^{11}$ SADDY, André; GRECO, Rodrigo. Termo de Ajustamento de Conduta em

Procedimentos Sancionatórios Regulatórios. Revista de Informação Legislativa, Vol. 52, 206, 2015. 


\section{Pioneirismo: o Conselho AdMinistrativo De Defesa ECONÔMICA}

O exemplo do CADE pode ser um parâmetro interessante para demonstrar o avanço de uma política de acordos com particulares (excluindo-se, naturalmente, alguns aspectos que são pertinentes aos processos daquele órgão), que recebe o nome de Termo de Compromisso de Cessação de Prática (TCC). O TCC pode ser celebrado por pessoas físicas e jurídicas investigadas por infrações à ordem econômica, após o que se suspende o prosseguimento das investigações em relação aos agentes privados enquanto estiverem cumprindo os termos do acordo, ao passo que se comprometem a cumprir as obrigações expressas nele.

O TCC surgiu no ordenamento brasileiro com a Lei no 8.884/1994, a qual regulamentava diversos aspectos do Direito da Concorrência no Brasil. Essa legislação autorizava o CADE a celebrar TCC com investigados pelo cometimento de práticas anticompetitivas. A partir da celebração, suspendia-se o processo administrativo, desde que o investigado cessasse aquelas práticas e fornecesse relatórios sobre a sua atuação no mercado. Cumpridas essas condições, era extinto e arquivado o processo administrativo correspondente. Inicialmente, a celebração de TCC não importava na confissão ou no reconhecimento da ilicitude da conduta sob análise (art. 53, Lei no 8.884/1994).

Em decorrência, entretanto, de inovação legislativa trazida pela Lei $n^{0}$ 10.149/2000, qual seja o Acordo de Leniência, houve mudanças significativas na regulamentação dos TCCs no âmbito do CADE. De pronto, deixou de ser possível a celebração de TCC em casos de cartel (art. 21, I, II, III e VIII da Lei no 8.884/1994), com o objetivo de promover a utilização daquele novo instrumento nesses casos. Essa situação perdurou até a promulgação da Lei $\mathrm{n}^{\mathrm{o}} 11.482 / 2007$, a qual (re)autorizou a celebração de TCC "em qualquer das espécies do processo administrativo". Também em 2007, o CADE editou a Resolução $n^{\mathbf{o}}$ 46/200712 que regulamentou o artigo 53 da Lei 8.884/1994, com a redação dada pelo artigo 16 da Lei 11.482/2007. Essa resolução previa, em seu art. 129-G, que nos casos em que tivesse havido acordo de leniência, o TCC deveria conter reconhecimento de culpa e que, mesmo nos demais, a

12 O texto completo da Resolução no 46/2007 do CADE se encontra disponível em:

$<$ http://www.cade.gov.br/assuntos/normas-e-

legislacao/resolucao/resolucao46.pdf/view>. Acesso em: 14 de julho de 2017. 
exigência de confissão de culpa ficaria a critério do CADE. ${ }^{13}$ Previa também a necessidade de adoção, pela parte, de um programa de prevenção de infrações à ordem econômica (art. 129-A, III).

Essa sistemática sofreu nova transformação com a nova Lei Antitruste, a Lei $n^{0}$ 12.529/2011, e com a Resolução $n^{0}$ 5/2013 $3^{14}$ que regulamentou a celebração de TCC nesse novo cenário normativo. Alguns pontos dessa sistemática, atualmente em vigor, merecem nota. Podem os interessados propor a celebração de TCC durante procedimento preparatório do inquérito administrativo, durante o inquérito administrativo ou no curso do processo administrativo (art. 179). Será responsável pela discussão sobre os termos do acordo a Comissão de Negociação, indicada pelo Superintendente-Geral do CADE (art. 181) ou pelo Conselheiro-Relator (art. 182), a depender momento processual.

Mantém-se a regra exigindo reconhecimento de culpa quando da celebração de TCC em casos de investigação de acordo, combinação, manipulação ou ajuste entre concorrentes (art. 185). Exige-se, do compromissário, que colabore com a instrução processual, apresentando informações relevantes para investigações (art. 186). Manteve-se também a exigência de contribuição pecuniária ao Fundo de Direitos Difusos, inaugurada com a Lei $\mathrm{n}^{\mathrm{o}} 11.482 / 2007$, embora tenha se previsto escalonamento, com reduções proporcionais maiores das contribuições pecuniárias para os primeiros propositores de TCCs, sob a presunção de que estes têm maiores informações a contribuir para a investigação (art. 187). Assim, a contribuição será calculada, admitindo descontos escalonados (i) uma redução de $30 \%$ a $50 \%$ para o primeiro proponente de TCC, (ii) uma redução de $25 \%$ a $40 \%$ para o segundo proponente de TCC e (iii) uma redução de até $25 \%$ para os demais proponentes de TCC. Se o TCC for proposto após os autos serem encaminhados ao Tribunal do

${ }^{13}$ A mudança do caput do art. 53 da redação original ("Em qualquer fase do processo administrativo poderá ser celebrado, pelo CADE ou pela SDE ad referendum do CADE, compromisso de cessação de prática sob investigação, que não importará confissão quanto à matéria de fato, nem reconhecimento de ilicitude da conduta analisada") para a redação dada pela Lei nº 11.482/2007 ("Em qualquer das espécies do processo administrativo, o CADE poderá tomar do representado compromisso de cessação da prática sob investigação ou dos seus efeitos lesivos, sempre que, em juízo de conveniência e oportunidade, entender que atende aos interesses protegidos por lei") já apontava para esse caminho.

${ }^{14} \mathrm{O}$ texto completo da Resolução no 5/2013 se encontra disponível em: $<$ http://www.cade.gov.br/assuntos/normas-e-legislacao/resolucao/resolucao5 2013.pdf/view>. Acesso em: 14 de julho de 2017. 
CADE, o desconto será de até $15 \%$.

Nota-se que, inicialmente, o CADE se preocupou em incentivar o uso do instrumento, para angariar mais agentes interessados no TCC. Aos poucos, o CADE foi endurecendo a sua política regulatória, impondo requisitos mais exigentes para os agentes econômicos - a Lei $\mathrm{n}^{\mathbf{0}}$ 12.529/2011, acompanhada da Resolução no 5/2013, é a maior prova disso. Entretanto, tais requisitos não afetaram o sucesso da política de TCCs.

Desde a edição da Lei no 8.884/1994 até 2010, o CADE celebrou 56 instrumentos de TCCs, dos quais 31 eram casos de cartel. ${ }^{15}$ Essa realidade mudou drasticamente com o advento da Lei $\mathrm{n}^{\circ}$ 12.529/2011: a partir de 2013, a política de TCC cresceu exponencialmente, com a edição de regulamentos dando maior clareza sobre os benefícios e requisitos daquele instrumento.

Gráfico 2:

Número de TCCs firmados pelo CADE

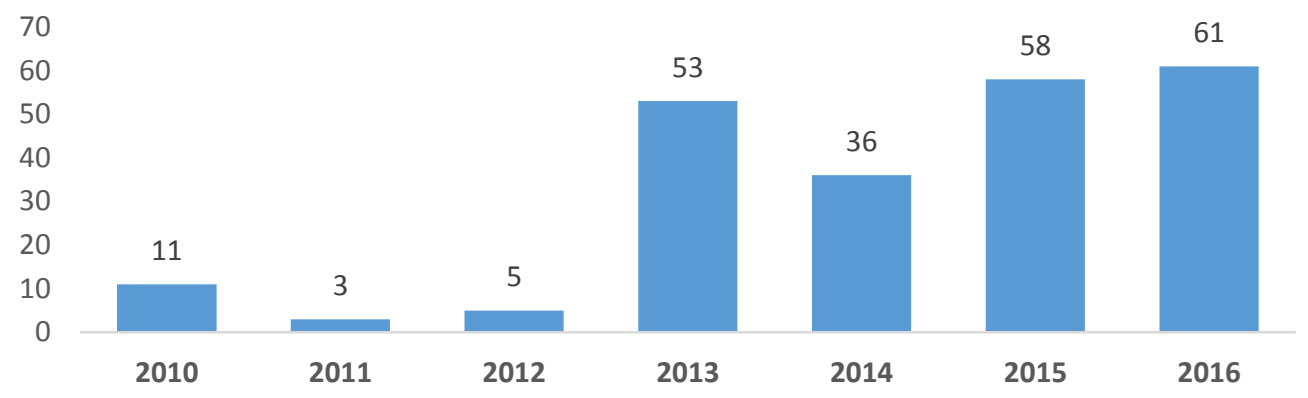

Fonte: CADE. ${ }^{16}$

${ }^{15}$ PEREIRA, Guilherme Teixeira. Política de Combate a Cartel no Brasil: Análise Jurídica do Acordo de Leniência e do Termo de Compromisso de Cessação de Prática. Dissertação (Mestrado em Direito e Desenvolvimento Econômico e Social) Escola de Direito de São Paulo, Fundação Getulio Vargas, São Paulo, 2011, p. 53.

${ }^{16}$ Ressalva se faz ao ano de 2013 que, apesar dos 53 TCCs celebrados, 42 deles decorreram dos casos de unimilitância da Unimed. CONSELHO ADMINISTRATIVO DE DEFESA ECONÔMICA. Balanço 2016. Brasília, 2017. Disponível em: $<$ http://www.cade.gov.br/servicos/imprensa/balancos-e-apresentacoes/apresentacaobalanco-2016.pdf/view>. Acesso em: 17 de julho de 2017. 
O aumento do número de TCCs celebrados foi acompanhado de significativo incremento das contribuições pecuniárias no CADE. Revertidas para o Fundo de Defesa dos Direitos Difusos, essas contribuições geraram também um importante crescimento desse fundo, já que constituem sua principal fonte de recursos. ${ }^{17}$

\section{Gráfico 3:}

Evolução de Contribuições Pecuniárias em TCC

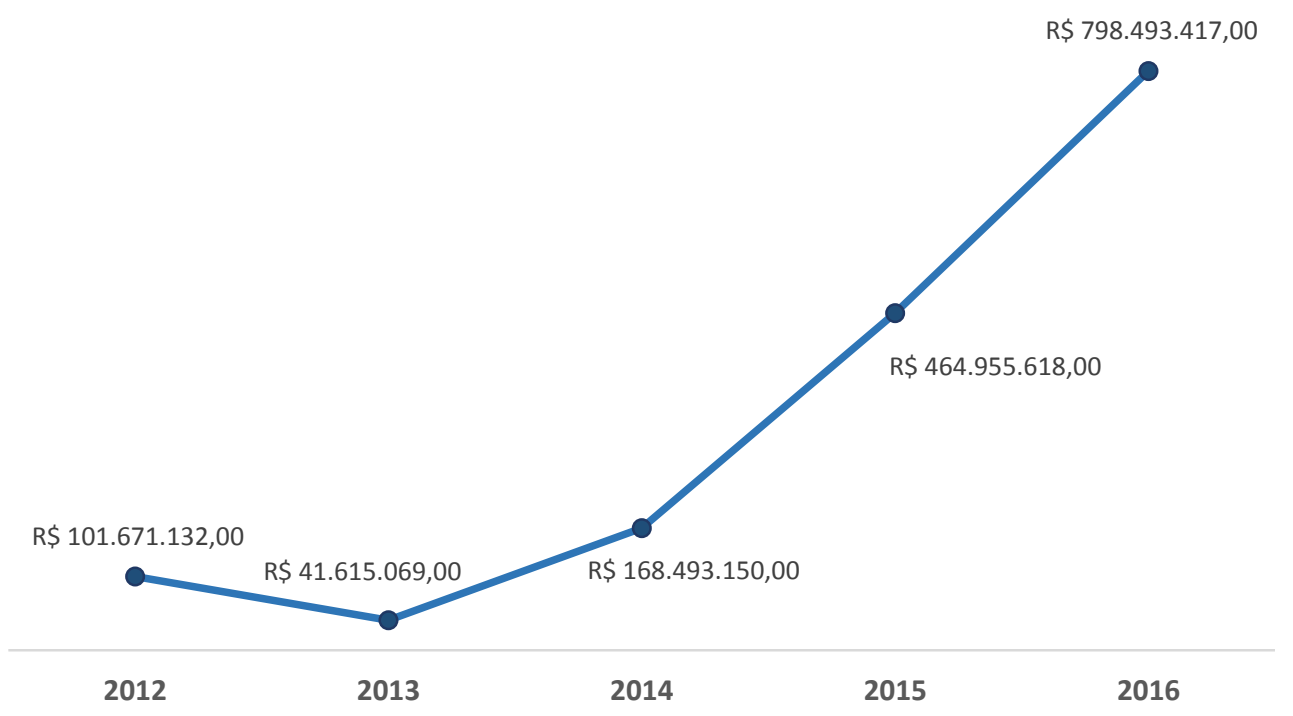

Fonte: CADE. ${ }^{18}$

Um importante elemento nesse processo de oferecer maior certeza e precisão sobre a negociação e sobre os próprios termos do TCC foi a edição do Guia para Termo de Compromisso de Cessação para casos de Cartel, em 2016. ${ }^{19}$ O Guia oferece informações detalhadas sobre todo o

${ }^{17}$ CARNEIRO FILHO, Humberto João. Estrutura, Funcionamento e Evolução do Fundo de Defesa dos Direitos Difusos. Revista Jurídica da Seção Judiciária de Pernambuco, No. 3, 2010, p. 104.

${ }^{18}$ CONSELHO ADMINISTRATIVO DE DEFESA ECONÔMICA. Balanço 2016. Brasília, 2017. Disponível em: $<$ http://www.cade.gov.br/servicos/imprensa/balancos-eapresentacoes/apresentacao-balanco-2016.pdf/view>. Acesso em: 17 de julho de 2017. ${ }^{19}$ CADE. Guia Termo de Compromisso de Cessação para casos de cartel. Brasília, 2016. Disponível em: $<$ http://www.cade.gov.br/acesso-a-informacao/publicacoes- 
procedimento junto ao $\mathrm{CADE}$, compilado a partir das melhores práticas e procedimentos usualmente adotados. Trata, por exemplo, minuciosamente da apresentação do requerimento por eventuais interessados, inclusive da valoração das informações a serem fornecidas, da contribuição pecuniária e dos parâmetros para sua fixação (base de cálculo, alíquotas, agravantes e atenuantes) e da inter-relação entre o TCC e o acordo de leniência. Assim, o Guia se tornou uma importante ferramenta para conferir maior legitimidade ao processo de celebração de TCC, oferecendo maior segurança jurídica ao agente privado.

O resultado disso é que os agentes econômicos têm a possibilidade de se planejar e calcular as vantagens e desvantagens da celebração de um TCC. Acompanhada de uma crescente eficiência na política fiscalizatória, se multiplicam os incentivos para que abandonem práticas delituosas e busquem adequar suas condutas às normas concorrenciais brasileiras, de forma célere e menos custosa. Representando uma alternativa à judicialização e oferecendo reduções às multas aplicada, o TCC se tornou um importante instrumento regulatório no combate às práticas anticompetitivas.

A prática de TCCs no âmbito do CADE constitui realidade bastante particular quando comparada aquela das agências reguladoras de infraestrutura no âmbito federal. O nível de incremento normativo é consequência de um longo processo de evolução no qual algumas das agências estão dando apenas os primeiros passos. Pode servir, entretanto, como parâmetro e referência para os próximos passos desse processo evolutivo.

\section{TACs nas AgênCIAs Reguladoras Federais de}

\section{INFRAESTRUTURA}

A prática efetiva das agências reguladoras no que se refere à celebração de TACs representa um ponto ainda pouco explorado por parte da doutrina nacional. Dessa forma, além de apresentar as bases normativas sobre as quais se efetivam essa prática, pretende-se, também, diagnosticar o quanto e como esses TACs vêm sendo celebrados, com o propósito de melhor compreender o funcionamento desse importante instrumento.

Independente de previsão específica, que a maioria das agências têm

institucionais/guias do Cade/guia-tcc-versao-final.pdf $>$. Acesso em: 10 de julho de 2017. 
contemplada em seu ordenamento, existem normas gerais que dão guarida à celebração de acordos entre a Administração Pública e particulares, nos moldes do TAC. A Lei da Ação Civil Pública, por exemplo, em seu art. 5o, prevê a competência de autarquias celebrarem compromissos de ajustamento de condutas. ${ }^{20}$ De forma semelhante, a Lei no 12.249/2010 acrescentou dispositivos à Lei $\mathrm{n}^{-}$9.469/1997, que trata da atuação da União nas causas em que figuram como autores ou réus entes da administração indireta, para prever também a possibilidade de celebração de termo de ajustamento de conduta, por autarquias, com objetivo de prevenir ou terminar litígios. ${ }^{21}$

Resta, assim, pouca dúvida sobre legalidade da celebração de TACs por agências reguladoras, mesmo na ausência de previsão legal expressa..$^{22}$ Importa, portanto, compreender a prática dessa celebração. Para isso, foram selecionadas a Agência Nacional de Transportes Terrestres (ANTT), a Agência Nacional de Transportes Aquaviários (ANTAQ), a Agência Nacional de Aviação Civil (ANAC), Agência Nacional de Telecomunicações (ANATEL), a Agência Nacional de

${ }^{20}$ Art. 5 - "Têm legitimidade para propor a ação principal e a ação cautelar: IV - a autarquia, empresa pública, fundação ou sociedade de economia mista;

${ }^{21}$ Art. 4⿳-口-A - "O termo de ajustamento de conduta, para prevenir ou terminar litígios, nas hipóteses que envolvam interesse público da União, suas autarquias e fundações, firmado pela Advocacia-Geral da União, deverá conter: I - a descrição das obrigações assumidas; II - o prazo e o modo para o cumprimento das obrigações; III - a forma de fiscalização da sua observância; IV - os fundamentos de fato e de direito; e V - a previsão de multa ou de sanção administrativa, no caso de seu descumprimento. Parágrafo único. A Advocacia-Geral da União poderá solicitar aos órgãos e entidades públicas federais manifestação sobre a viabilidade técnica, operacional e financeira das obrigações a serem assumidas em termo de ajustamento de conduta, cabendo ao Advogado-Geral da União a decisão final quanto à sua celebração".

${ }^{22}$ Respondendo a esses questionamentos, André Saddy e Rogério de Azevedo Greco afirmam que "É natural que a normatização preveja casos e condições em que ações posteriores do infrator (capazes de eliminar ou compensar danos e vantagens) podem atenuar ou mesmo evitar a sanção. Infere-se, dessa forma, que cabe às agências reguladoras, no uso de sua competência normativa, disporem sobre as causas determinantes e excludentes da aplicação ou execução das sanções. Para tanto, poderão utilizar-se do seu poder normativo para regulamentar acordos substitutivos/suspensivos em procedimentos sancionatórios regulatórios". SADDY, André; GRECO, Rodrigo. Termo de Ajustamento de Conduta em Procedimentos Sancionatórios Regulatórios. Revista de Informação Legislativa, Vol. 52, 206, 2015, p. 180.

3 JOURNAL OF INSTITUTIONAL STUDIES 1 (2017) 
Energia Elétrica (ANEEL), a Agência Nacional de Águas (ANA) e a Agência Nacional do Petróleo, Gás Natural e Biocombustível (ANP) como alvos de estudo de casos comparativo.

Esses estudos de caso foram realizados a partir de fontes primárias, originárias de uma pesquisa documental e, principalmente, de pedidos de acesso à informação com base na Lei de Acesso à Informação. Por meio desses pedidos, pretendeu-se compreender a política de celebração de acordos em cada uma das agências, assim como a prática efetiva, com destaque para o número de TACs realizados por cada uma delas. Não se pretendeu, nesse momento, realizar análise qualitativa dos mesmos.

\section{Agência Nacional de Transportes Terrestres}

A Agência Nacional de Transportes Terrestres foi uma das primeiras a prever a possibilidade de celebração de TACs no âmbito de processos administrativos internos. Essa previsão surgiu com a Resolução $n^{\mathbf{0}} 152$ de 2003, a qual previu, inicialmente, o emprego desse instrumento "para o propósito de correção de pendência ou irregularidades cometidas por concessionários e permissionárias de serviços públicos de transporte terrestre". ${ }^{23}$ A Resolução $\mathrm{n}^{\mathrm{o}}$ 152/2003 atribuía competência descentralizada às Superintendências da ANTT para firmar TACs, estabelecendo, no entanto, curto prazo para o saneamento de irregularidades ou pendências: apenas 30 dias. Chama atenção também para o fato de que o TAC não constituía causa suspensiva à instauração de processo administrativo ${ }^{24}$, tendo em vista que o art. 5 daquela resolução previa que "a celebração do TAC não impedirá que a ANTT possa, se assim entender, deflagrar o processo administrativo para apurar as mesmas irregularidades".

A questão do prazo foi superada com a edição da Resolução $n^{0}$ 442/2004, a qual não previa um limite máximo fixo e ainda autorizava a Diretoria da ANTT a, caso necessário, prorrogar o prazo autorizado pela Superintendência competente. Quanto à suspensão do processo

${ }^{23}$ O texto completo da Resolução no 152/2003 da ANTT se encontra disponível em: $<$ http://www.normasbrasil.com.br/norma/resolucao-152-2003 99109.html >. Acesso em: 14 de julho de 2017.

${ }^{24}$ Razão pela qual André Saddy e Rogério Azevedo Greco afirmam não se tratar propriamente de Termo de Ajustamento de Conduta, mas sim de Medida Reparadora de Conduta. SADDY, André; GRECO, Rodrigo. Termo de Ajustamento de Conduta em Procedimentos Sancionatórios Regulatórios. Revista de Informação Legislativa, Vol. 52, 206, 2015, p. 176. 
administrativo, a referida resolução era contraditória. Enquanto o art. 16, em seu parágrafo único, repetia o dispositivo da resolução n⿳o 152/2003 sobre o tema, o art. $17, \S 2^{\circ}$ afirmava que "no transcurso do prazo fixado [no TAC], o processo administrativo, se instaurado, ficará suspenso" ${ }^{25}$ Ou seja, o processo administrativo poderia ser iniciado, porém já surgiria suspenso. Esse ponto foi equacionado com a Resolução no 847/2005, que revogou o art. 16, p.u., confirmando que a celebração de TAC, no âmbito da ANTT, representaria causa suspensiva efetivamente.

Atualmente, regulamenta a celebração de TACs a Resolução $n^{0}$ 5.083/2016 que revogou a Resolução $\mathrm{n}^{\mathrm{o}}$ 442/2004, embora tenha essencialmente preservado a sistemática vigente desde 2005. Em resumo, a Resolução no 5.083/2016 atribuiu a competência para a propositura e celebração de TACs às Superintendências competentes e também à Diretoria da $\mathrm{ANTT}^{26}$; manteve flexíveis os limites temporais para a resolução de irregularidades ou pendências; e confirmou que os processos administrativos ficam suspensos durante o transcurso do prazo previsto no TAC. ${ }^{27}$

Existem, no entanto, algumas lacunas. Não há qualquer menção acerca de a assinatura do TAC importar ou não em confissão quanto às matérias de fato ou sobre ilicitude da conduta, ou mesmo como será calculado o valor da multa no TAC. A fiscalização do cumprimento dos termos do acordo ficará a cargo da autoridade competente, conforme prevê o art. 16 da Resolução ${ }^{0}$ 5.083/2016. Como mencionado, a política regulatória da ANTT permite que a Diretoria Colegiada ou que as Superintendências de Processos Organizacionais (SUPAS, SUINF, SUFER) proponham, antes da instauração ou até o encerramento do processo administrativo, a celebração de TAC. Portanto, a compilação do número total de TACs celebrados pela ANTT exige que se considerem as ações de todos esses órgãos. Em termos absolutos, foram 35 TACs celebrados até 2015, sendo 17 da SUFER, 14 da SUINF e 4 da SUPA:

${ }^{25}$ O texto completo da Resolução no 442/2004 da ANTT se encontra disponível em: $<$ http://www.normasbrasil.com.br/norma/resolucao-442-2004 100024.html >. Acesso em: 14 de julho de 2017.

${ }^{26}$ Não há menção à possibilidade dos agentes regulados iniciarem esse procedimento. A própria Resolução nº 5.083/2016 atribui àqueles órgãos a possibilidade de "convocar" os agentes regulados para prestação de esclarecimentos e, eventualmente discussões sobre um TAC (art. 14).

${ }^{27}$ O texto completo da Resolução no 5.083/2016 da ANTT se encontra disponível em: $<$ http://portal.antt.gov.br/index.php/content/view/46843/Resolucao n 5083.html $>$. Acesso em: 14 de julho de 2017. 


\section{Gráfico 4:}

Número de TACs celebrados por ano pela ANTT

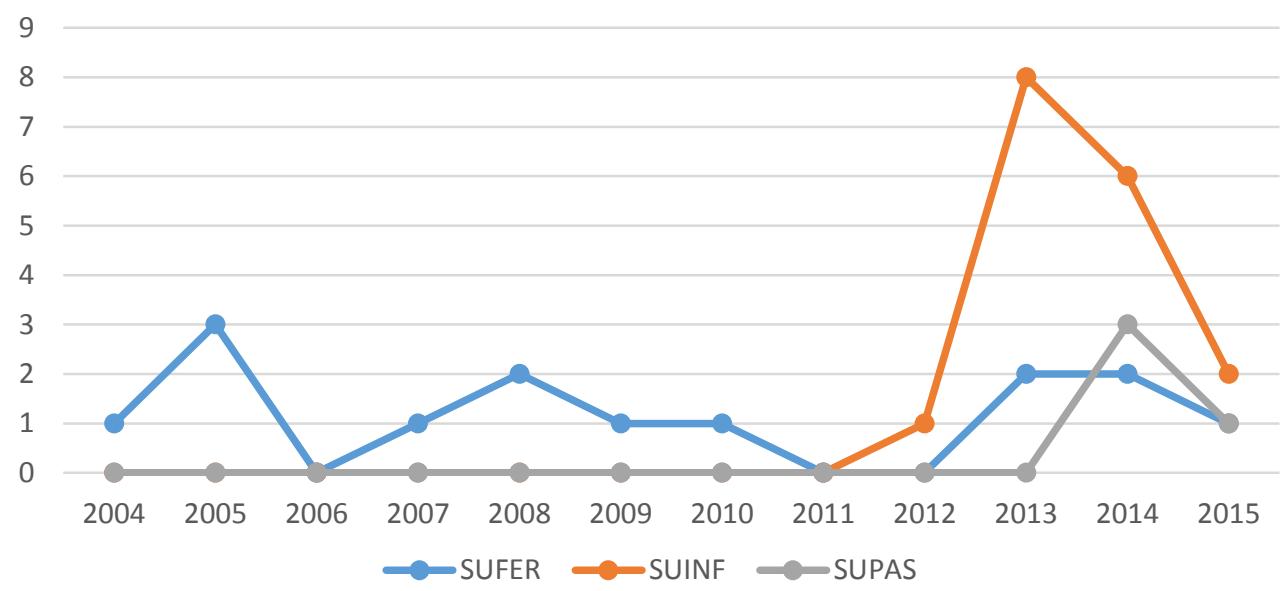

Fonte: Elaboração própria a partir de dados fornecidos pela ANTT..$^{28}$

Dada a recente alteração normativa, com a edição da Resolução $n^{0}$ $5.038 / 2016$, ainda não é possível diagnosticar os possíveis impactos desta na prática efetiva da ANTT.

\section{Agência Nacional de Transportes Aquaviários}

A Agência Nacional de Transportes Aquaviários previu, inicialmente, a possibilidade de celebração de TAC na Resolução no 987/2008. ${ }^{29}$ Regulamentando o processo administrativo no âmbito da ANTAQ, esta resolução previa, em seu art. 15, que competia às Superintendências, às Gerências de Fiscalização e às Unidades Administrativas Regionais ${ }^{30}$

${ }^{28}$ Pedido de Acesso à Informação à ANTT. Processo no 50650001331201737. Data da abertura: 18/04/2017.

${ }^{29}$ O texto completo da Resolução no 987/2008 da ANTAQ se encontra disponível em: $<$ http://web.antaq.gov.br/portalv3/pdfSistema/Publicacao/0000008286.pdf $>$. Acesso em: 14 de julho de 2017.

${ }^{30}$ Essa descentralização é mitigada pela necessidade de as Gerências de Fiscalização e UARs obterem autorização da Superintendência competente (art. 22, §2 ${ }^{\circ}$ da Resolução no 987/2008). 
oferecerem a possibilidade de correção de eventuais irregularidades, constantes em Relatório de Fiscalização, por meio do estabelecimento de um TAC. Oferecida essa possibilidade de negociação, a pessoa física ou jurídica teria o prazo de cinco dias para manifestar o interesse em celebrar o TAC.

Aos moldes do previsto pelas Resoluções no 442/2004 e 847/2005 da ANTT, a Resolução no 987/2008 oferece ampla flexibilidade para o prazo a ser imposto para correção de irregularidades e pendências, assim como determina a suspensão do processo administrativo, a partir da celebração do TAC. Atribui também competência fiscalizatória, sobre os termos do TAC, à autoridade que o celebrou (art. 24).

A partir da edição da Resolução no 3.259/2014, a celebração de TACs no âmbito da ANTAQ passou a ser regulamenta pelo art. 83 e seguintes daquela resolução. Estabelece esta resolução que a propositura do TAC somente poderá ser feita até a emissão de Parecer Técnico Instrutório. O texto do artigo 84 merece destaque por afirmar que a decisão, pela autoridade administrativa sobre a celebração de TACs deve ser "excepcional e devidamente justificada". ${ }^{31}$ Acrescenta, ainda, três requisitos aos TACs, não previamente exigidos: (i) consideração justificando a celebração do TAC; (ii) as cominações pelo seu descumprimento; e (iii) a responsabilidade das partes, identificando-se o responsável pelo acompanhamento do TAC (art. 86). Nota-se, portanto, um incremento regulatório em relação a normas prévias.

A resolução é silente quanto ao reconhecimento ou confissão de culpa, mas menciona que a multa prevista pelo inadimplemento do TAC deverá ser de, no mínimo, o teto da sanção pecuniária prevista (art. 84, §3ํㅜ). A fiscalização do cumprimento dos termos do acordo ficará a cargo da Autoridade Julgadora competente da ANTAQ.

Há uma restrição em relação aos dados fornecidos pela ANTAQ. Apesar de a política de TACs estar em vigor na agência desde 2008, somente a partir de 2014, a ANTAQ desenvolveu sistema para coleta e organização dos TACs celebrados. Assim, chegou-se ao número total de 55 TACs firmados desde 2014 (até abril/2017), com a seguinte distribuição anual:

${ }^{31}$ O texto completo da Resolução no 3.259/2014 da ANTAQ se encontra disponível em: $<$ http://web.antaq.gov.br/Portal/pdfSistema/Publicacao/0000008678.pdf $>$. Acesso em: 14 de julho de 2017. 


\section{Gráfico 5:}

Número de TACs celebrados por ano pela ANTAQ

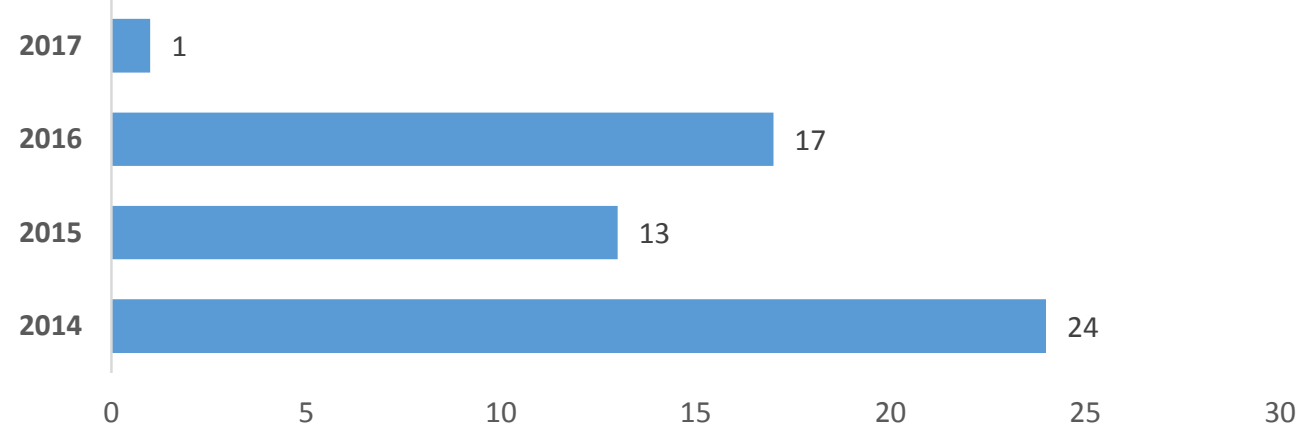

Fonte: Elaboração própria a partir de dados fornecidos pela ANTAQ. ${ }^{32}$

\section{Agência Nacional de Aviação Civil}

A Agência Nacional de Aviação Civil foi uma das últimas agências reguladoras federais a instituir o instrumento do TAC, o fazendo por meio da Resolução no 199/2011. ${ }^{33}$ Por meio dessa resolução, a ANAC esclarece que sua política de acordos tem como objetivo adequar a conduta dos agentes por ela regulados: “(i) às exigências previstas nas normas aplicáveis; ou (ii) às melhores práticas para garantir a segurança operacional ou manter a adequação do serviço público prestado ao usuário de transporte aéreo" (art. 2). Chama atenção o fato de que TACs poderão ser celebrados mesmo na segunda hipótese, quando as circunstâncias não sequer se configuram como infrações administrativas, ampliando, em tese, o escopo para a aplicação desse instrumento.

A Resolução no 199/2011 prevê a possibilidade de proposição do TAC tanto pelas autoridades competentes da ANAC, quanto pelos agentes regulados, nesse último caso no curso do processo administrativo para

32 Pedido de Acesso à Informação à ANTAQ. Processo no 50650001329201768. Data de abertura: 18/04/2017.

${ }^{33}$ O texto completo da Resolução no 199/2011 da ANAC se encontra disponível em: $<$ http://www.anac.gov.br/assuntos/legislacao/legislacao-1/resolucoes/resolucoes2011/resolucao-no-199-de-13-09-2011/@@display-file/arquivo norma/RA20110199.pdf>. Acesso em: 14 de julho de 2017. 
apuração de infração e penalidades, juntamente com a defesa. Diferente das regulamentações previamente mencionadas, a política de acordos da ANAC reconhece, em seu art. 4, que a proposição e a celebração de TAC não importam em confissão ou reconhecimento de conduta ilícita pelo agente.

Há uma clara distribuição de competências internas para a celebração de TACs na ANAC. Os casos considerados mais graves ou importantes ${ }^{34}$ são reservados à Diretoria, enquanto os de menor vulto são de competência do Superintendente responsável pela área temática afeta ${ }^{35}$, que também será responsável pela fiscalização do cumprimento do TAC celebrado (art. 5). A Resolução no 199/2011 também estabelece quais são as cláusulas essenciais aos TACs, dentre as quais merece destaque aquelas relativas à preocupação com a tempestividade do seu cumprimento. ${ }^{36}$ Deve conter o TAC cronograma de atendimento e realização das medidas corretivas, as penalidades decorrentes do atraso no cumprimento desse cronograma e a periodicidade do envio de informações pelo celebrante, comprovando o cumprimento do cronograma. Requer-se também a "expressa menção à natureza executiva do termo celebrado" (art. 6).

Por fim, anota-se o fato de a ANAC atenuar substancialmente o caráter suspensivo do TAC em relação ao processo administrativo relacionado, diferente das agências previamente estudadas. Afirma o art. 6, §5ํㅡ da Resolução no 199/2011: “Excepcionalmente e de forma fundamentada, desde que haja medida eficaz para preservar o interesse público, o TAC poderá prever a suspensão de processos administrativos com o Auto de Infração lavrado". Ou seja, a suspensão do processo

34 "Art. 5 - Compete à Diretoria da ANAC decidir sobre a celebração do TAC nos casos em que exista processo administrativo em curso para: I - autuação ou conjunto de autuações com multas aplicadas cujo valor total estimado seja superior a $R \$ 100.000,00$ (cem mil reais). II - cassação ou suspensão de concessões ou autorizações para a exploração de serviço público, ou suspensão parcial ou total da operação de prestadoras de serviços aéreos; III - interdição parcial ou total de aeródromo público". ${ }^{35}$ Exemplos: Superintendência de Infraestrutura Aeroportuária, Superintendência de Padrões Operacionais, Superintendência de Acompanhamento de Serviços Aéreos, Superintendência de Regulação Econômica de Aeroportos, Superintendência de Aeronavegabilidade e Superintendência de Ação Fiscal.

${ }^{36}$ Encontra-se disponível a Portaria no 534 de 2012 da ANAC, com o modelo de TAC a ser assinado entre a ANAC e os agentes regulados, em:

$<$ http://www.anac.gov.br/assuntos/legislacao/legislacao-1/portarias/portarias2012/portaria-no-0534-dir-de-23-03-2012/@@display-file/arquivo norma/PA20120534.pdf $>$. Acesso em: 14 de julho de 2017. 
administrativo parece ser a exceção e não a regra nos casos de celebração de TAC. Além disso, a celebração do TAC não afasta definitivamente a possibilidade de adoção de novas medidas administrativas cautelares pela ANAC (art. 6, $\S 6^{\circ}$ ).

Um dos principais, se não o principal incentivo à celebração do TAC é a suspensão do processo administrativo e, consequentemente, o adiamento e, caso bem-sucedido, o cancelamento das sanções impostas. Se a suspensão do processo administrativo não é garantida àqueles agentes que celebram TACs, no âmbito da ANAC, reduzem-se os incentivos para que eles o façam. Assim, permanece pequeno o número de termos celebrados pela ANAC, mesmo tantos anos após a sua regulamentação.

A ANAC celebrou apenas 2 TACs desde a adoção de política regulatória em 2011, sendo um deles com o governo do Estado de Minas Gerais, concernente à segurança dos aeroportos de Diamantina, Patos de Minas e São João del Rey (Processo administrativo 00058.013102/2012-71, de 18/09/2012), e o outro com a Passaredo Transportes Aéreos Ltda. (Processo administrativo 00066.018138/2014-12, de 22/04/2014). ${ }^{37}$

\section{Agência Nacional de Telecomunicações}

A possibilidade de a Agência Nacional de Telecomunicações vir a celebrar TACs com infratores já era prevista no art. 5 da Resolução no 589/2012. Foi, entretanto, apenas com a Resolução no $629 / 2013^{38}$ que essa negociação foi efetivamente regulamentada. Esta resolução prevê, inicialmente, que têm legitimidade para propor um TAC tanto a própria ANATEL, de ofício, quanto os agentes regulados.

A decisão sobre a celebração do TAC é bifásica: primeiramente, há juízo de admissibilidade sobre o requerimento apresentado, por parte do Superintendente competente (art. 7); em seguida, a decisão final é competência do Conselho Diretor da ANATEL (art. 11). Existem uma série de restrições que serão consideradas no momento daquele juízo de admissibilidade, principalmente relativas a comportamentos prévios por parte de requerentes em TACs anteriores. Uma cláusula restritiva,

${ }^{37}$ Pedido de Acesso à Informação à ANAC. Processo: 00086000217201773. Data de abertura: 8/05/2017.

${ }^{38}$ O texto completo da Resolução no 629/2013 da ANATEL se encontra disponível em: $<$ http://www.anatel.gov.br/legislacao/resolucoes/2013/680-resolucao-629>. Acesso em: 14 de julho de 2017. 
entretanto, é bastante ampla e genérica, autorizando a inadmissão de requerimentos "quando, em avaliação de conveniência e oportunidade, não se vislumbrar interesse público na celebração do TAC" ${ }^{39}$ (art. 6, VII).

Uma vez admitido o requerimento, já se suspende o processo administrativo relativo e tem início o processo de negociação dos termos daquele acordo, responsabilidade da Comissão de Negociação que é integrada pelos Superintendentes de Planejamento e Regulamentação, de Relações com Consumidores, de Competição, de Fiscalização e de Controle de Obrigações. Autorizado pelo Conselho Diretor, o TAC é firmado pelo Presidente da ANATEL e importa no arquivamento dos processos administrativos a que ele se refere (art. 11).

O TAC deverá conter as seguintes cláusulas obrigatórias: (i) compromisso de ajustamento da conduta irregular, prevendo cronograma de metas e obrigações voltadas à regularização da situação da Compromissária e reparação de eventuais usuários atingidos, bem como à prevenção de condutas semelhantes; (ii) compromissos adicionais, nos termos do art. 18; (iii) meios, condições e a área de abrangência das condutas ajustadas e dos compromissos celebrados no TAC; (iv) obrigação de prestação de informações periódicas à Anatel sobre a execução do cronograma de metas e condições dos compromissos; (v) multas aplicáveis pelo descumprimento de cada item do cronograma de metas e condições dos compromissos, inclusive diárias pelo atraso na sua execução; (vi) relação de processos administrativos, com as respectivas multas aplicadas e estimadas, a que se refere o TAC; (vii) Valor de Referência a ser dado ao TAC, para fins de execução em caso de eventual descumprimento, nos termos previstos neste Regulamento; e, (viii) vigência, cujo prazo será improrrogável e não poderá ser superior a 4 (quatro) anos (art. 13).

Com referência ao inciso II, merece destaque o fato de a ANATEL exigir, além do ajuste da conduta irregular, compromissos que importem em benefícios diretos a usuários e/ou melhorias de serviços (art. 18), algo que não encontra referência explícita nas outras normas sob comento.

A fiscalização do cumprimento do TAC é competência da Superintendência de Controle de Obrigações (art. 23) que, não

${ }^{39} \mathrm{O}$ artigo 15 da Resolução n⿳0 629/2013 traz alguns critérios que trazem, em alguma medida, maior concretude a essa previsão: “I - a proporcionalidade da proposta em relação à gravidade da conduta em análise; II - a existência de motivos que recomendem que o ajustamento de determinada prática reputada irregular se dê gradualmente; III - a capacidade do TAC para evitar a prática de novas condutas semelhantes pela Compromissária, bem como para estimular o cumprimento da regulamentação; e, IV - a efetiva proteção dos direitos dos usuários". 
coincidentemente, também preside a Comissão de Negociação. $O$ processo de fiscalização, à semelhança do da ANAC, se atém de forma bastante específica ao cronograma de cumprimento das obrigações assumidas. $\mathrm{O}$ não cumprimento do cronograma previsto implicará a imposição de multa e, possivelmente, o encaminhamento de processo administrativo para a emissão de Certificado de Descumprimento, que é o "documento pelo qual o Conselho Diretor certificará o inadimplemento do TAC pela Compromissária, e liquidará o valor correspondente às multas cabíveis" (art. 31, p.u.). De outro lado, em caso de cumprimento pleno do TAC, o Conselho Diretor emitirá Certificado de Cumprimento.

Assim como Resolução nº 199/2011 da ANAC, a Resolução no 629/2013 da ANATEL prevê que o requerimento de TAC e a sua celebração não importam em confissão de culpa ou reconhecimento da ilicitude da conduta sob apuração (art. 5, §1ํ).

A ANATEL já celebrou 5 TACs (4 em 2004 e 1 em 2012)..$^{40}$ Esses números não incluem, entretanto, o TAC celebrado com a Telefonica/Vivo (outubro/2016), nem aquele celebrado com a Oi (maio/2016). Ambos dependiam da aprovação do TCU, o que não ocorreu até o momento. O TAC com a OI foi suspenso desde que a operadora entrou em recuperação judicial e aquele com a Telefonica foi alvo de críticas do TCU e sofreu uma complementação em maio/2017. Parte dessa complementação se referiu, possivelmente, a importantes desenvolvimentos no âmbito daquela agência, como a criação de um manual de acompanhamento dos compromissos acertados e o desenvolvimento de um gabinete de governança para acompanhamento das metas. ${ }^{41}$ Nota-se que o desenvolvimento das normas referentes a TACs está em progresso.

${ }^{40}$ Pedido de Aceso à Informação à ANATEL. Processo: 53850000391201774. Data de Abertura: 12/04/2017.

${ }^{41}$ Os detalhes completos sobre a complementação aprovada pelo Conselho

Deliberativo da ANATEL encontram-se disponíveis em:

$<$ https://sei.anatel.gov.br/sei/modulos/pesquisa/md pesq documento consulta extern a.php?eEPwqk1skrd8hSlk5Z3rN4EVg9uLJqrLYJw 9INcO431G1SETbYVVWSUMIt4OlEnFUAhKqpWXRKK1x6RPoU6qGScRLWda7VN44BBvtFYDL65CYpJFN5D8sULxdE5lV>. Acesso em: 17 de julho de 2017. Ainda não se afigura possível fazer uma análise da implementação desses novos mecanismos. 


\section{Agência Nacional de Energia Elétrica}

A Agência Nacional de Energia Elétrica encontra-se em situação peculiar no tocante ao tema sob estudo. Embora tenha tido regulamentação para a celebração de TACs, durante longo período, desde 2002, a revogação da Resolução no 333/2008 pôs fim àquela política no âmbito da ANEEL. A discussão em torno dessa revogação, especialmente pela análise do voto do relator do processo que a originou, na Diretoria Colegiada, todavia, fornece importantes subsídios à nossa análise.

A norma que inicialmente autorizava a celebração de TACs no âmbito

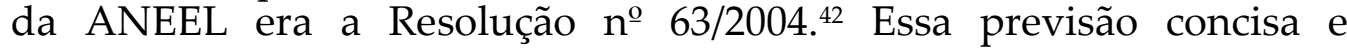
inespecífica foi incrementada com a edição da Resolução n⿳⺈ 333/2008. ${ }^{43}$ Essa resolução previa a possibilidade de os próprios agentes regulados solicitarem, no curso de processos fiscalizatórios, a celebração de TAC. Assim como na ANATEL, o processo decisório tinha, na ANEEL, duas fases: inicialmente, cabia à Superintendência de Fiscalização competente sobre a matéria ${ }^{44}$ emitir análise técnica sobre o pedido; posteriormente, caso a análise técnica houvesse sido favorável, caberia à Diretoria Colegiada decidir sobre a celebração do TAC.

A celebração do TAC implicava o arquivamento do processo administrativo correspondente e seu cumprimento deveria ser

42 "Art. 21. Poderá a ANEEL, alternativamente à imposição de penalidade, firmar com a concessionária, permissionária ou autorizada termo de compromisso de ajuste de conduta, visando à adequação da conduta irregular às disposições regulamentares e/ou contratuais aplicáveis. $\S 1^{\circ} \mathrm{O}$ termo de compromisso de ajuste de conduta será submetido à aprovação da Diretoria da ANEEL pela Superintendência onde o processo se originar. $\S 2^{\circ}$ As metas e compromissos objeto do termo referido neste artigo deverão, no seu conjunto, ser compatíveis com as obrigações previstas nos regulamentos e contratos regedores da prestação de serviços de energia elétrica descumpridas pela concessionária, permissionária ou autorizada. $3^{3^{\circ}}$ Do termo de compromisso de ajuste de conduta constará, necessariamente, o estabelecimento de multa pelo seu descumprimento, cujo valor será correspondente ao montante da penalidade que seria aplicada, acrescido de $20 \%$ (vinte por cento)." O texto completo da Resolução nº 63/2004 da ANEEL encontra-se disponível em:

$<$ https://www.legisweb.com.br/legislacao/?id=101128 $>$. Acesso em: 14 de julho de 2017.

${ }^{43} \mathrm{O}$ texto completo da Resolução ${ }^{\circ}$ 333/2008 da ANEEL encontra-se disponível em: $<$ https://www.diariodasleis.com.br/busca/exibelink.php?numlink=1-5-36-2008-10-09333>. Acesso em: 14 de julho de 2017.

${ }^{44}$ São três as Superintendências de Fiscalização: a de Serviços de Geração (SFG), a de Serviços de Eletricidade (SFE) e a Econômica e Financeira (SFF). 
fiscalizado pela Superintendência responsável. Mas não implicava em confissão de culpa ou reconhecimento de ilicitude (art. 7), assim como nos casos da ANATEL e da ANAC, anteriormente explicados. Também aos moldes da ANATEL, eventual descumprimento de TAC, na ANEEL, gerava emissão de Certificado de Descumprimento, o qual produzia diversos efeitos, entre os quais a impossibilidade de o agente regulado celebrar outro TAC no prazo de 4 anos, contados da constatação do descumprimento.

Foi no âmbito dos processos no $\mathrm{n}^{-}$48500.006161/2010-82 e 48500.006368/2010-57, que culminaram na orientação, pela Diretoria Colegiada da ANEEL, pela Revogação da Resolução no $333 / 2008$, que se apresentaram diversos dados relevantes sobre o funcionamento dos TACs no âmbito daquela agenda. Nesse sentido, o voto do DiretorRelator José Jurhosa Junior ${ }^{45}$ se mostrou extremamente informativo. ${ }^{46}$

Analisando apenas os TACs celebrados no âmbito da Superintendência de Fiscalização de Serviços de Eletricidade (SFE), Jurhosa Junior aponta que, entre 2002 e 2015, foram requeridos 103 TACs. Em 2008, com a edição da Resolução no 333, houve um aumento de 38\% no número de pedidos feitos, ocorrendo dois picos de 15 pedidos, nos anos de 2008 e 2010.

${ }^{45} \mathrm{O}$ voto do Diretor-Relator encontra-se disponível em $<$ http://www2.aneel.gov.br/cedoc/aren2016712 1.pdf $>$. Acesso em: 14 de julho de 2017.

${ }^{46}$ Demonstrou-se, de fato, a única fonte de informações sobre o tema relevante, tendo em vista que a resposta da ANEEL ao Pedido de Acesso à Informação (n⿳⺈ 48700001443201711, Data de abertura: 12/04/2017) foi completamente insatisfatória, tendo a agência se negado a fornecer informações que dispunha sob o argumento de que exigiria trabalho adicional de análise, nos termos do art. 13, III do Dec. 7.724/2012. 
Gráfico 6:

Número de TACs solicitados por ano à SFE

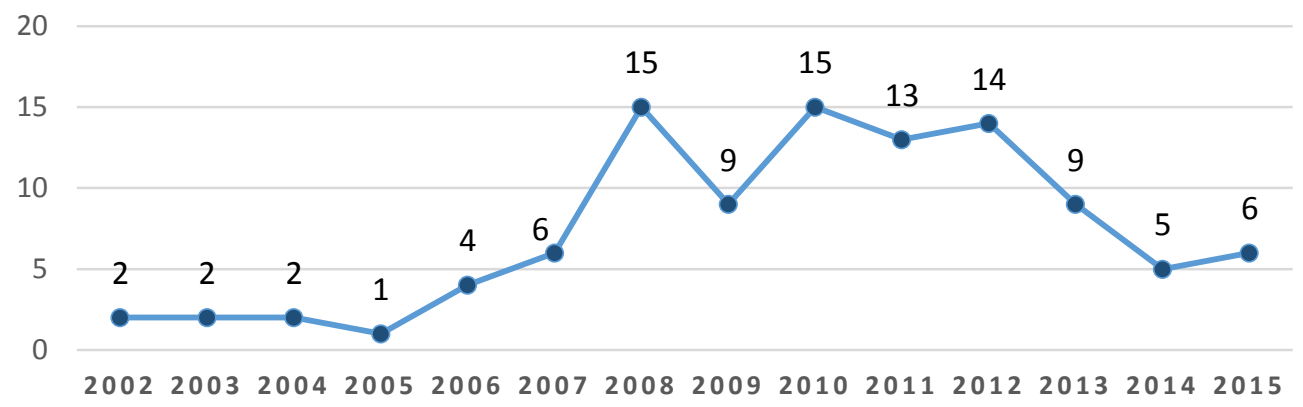

Fonte: ANEEL. ${ }^{47}$

Do universo de 103 pedidos, 54 pedidos (52\%) foram negados no âmbito da SFE; 18 pedidos (17\%) foram analisados pela SFE e pela Diretoria, porém concluídos sem assinatura do TAC (a média de tempo de análise foi de 567 dias); outros 6 estavam em fase de análise pela SFE (em abril de 2016); e, por fim, 25 pedidos (24\%) foram bem-sucedidos, levando a celebração de TACs.

\section{Gráfico 7:}

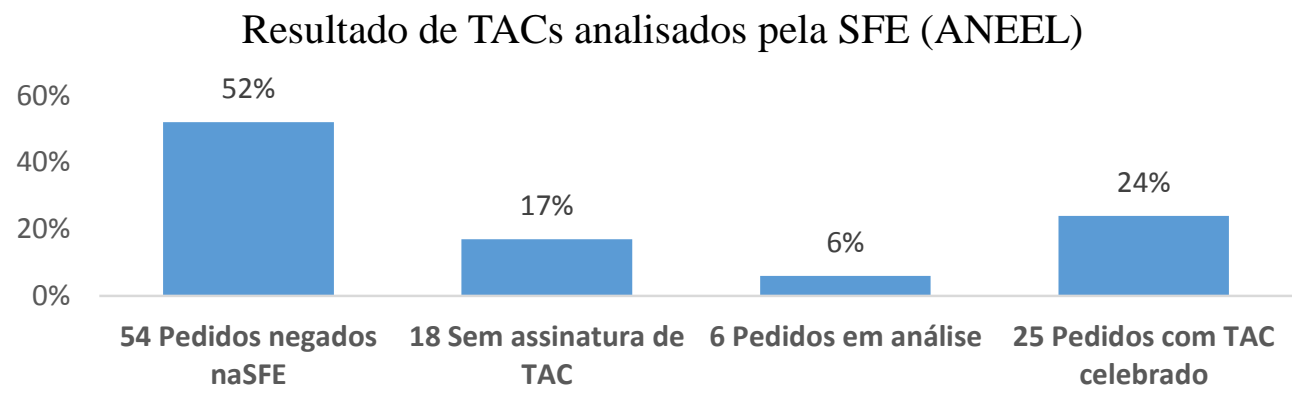

Fonte: ANEEL. ${ }^{48}$

${ }^{47}$ Gráfico elaborado a partir de dados constantes no voto do Diretor-Relator, o qual se

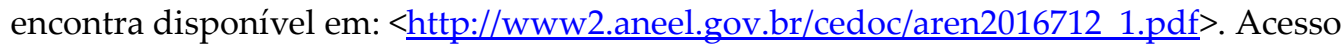
em: 14 de julho de 2017.

${ }^{48}$ Gráfico elaborado a partir de dados constantes no voto do Diretor-Relator, o qual se encontra disponível em: $<$ http://www2.aneel.gov.br/cedoc/aren2016712 1.pdf. Acesso em: 14 de julho de 2017. 
Dos 18 pedidos que chegaram à Diretoria, mas não culminaram na celebração de TAC, a principal razão apontada foi a desistência após o conhecimento das condições impostas por parte do agente regulado, o que sugere a existência de um problema de transparência a respeito do procedimento e critérios para a celebração de um acordo. Somente 25 TACs foram celebrados, sendo 8 vigentes em abril de 2015; dos 17 restantes nenhum foi cumprido integralmente, gerando Certificado de Descumprimento e aplicação de multas. A principal razão pelo não cumprimento dos TACs foi o não atingimento das metas de qualidade pactuadas.

Dessa forma, a conclusão da Diretoria-Colegiada da ANEEL pela revogação da Resolução n⿳o 333/2008 pode ser entendida como fundamentada em alguns fatores: (i) o baixo nível de eficácia em relação ao nível de cumprimento dos TACs celebrados; (ii) os excessivos custos processuais para a análise dos requerimentos de TACs, tendo em vista o reduzido percentual de TACs efetivamente celebrados, frente ao montante total requerido (24\%). Em conclusão, afirmou Jurhosa Junior: "o TAC não foi capaz de superar os ônus, as incertezas e a morosidade dos processos de fiscalização e de sanção, de modo a alcançar o interesse público".

Uma análise qualitativa dos TACs celebrados pela ANEEL, no período em que permaneceu em vigor a Resolução no 333/2008, resta necessária para que se compreenda o porquê do alto nível de nãocumprimento dos mesmos pelos agentes que os celebraram. Outro caminho promissor de pesquisa é a análise do processo administrativo no seio da ANEEL, para que se evidenciem os pontos que originavam atrasos na celebração dos termos e dificuldades no processo de fiscalização.

\section{Agência Nacional de Águas}

A Agência Nacional de Águas possui instrumento semelhante ao TAC com denominação diferente. Previsto na Resolução no ${ }^{6} 62 / 2010^{49}$, trata-se do Pacto de Compromisso (PC), que "se constitui no instrumento por meio do qual a ANA e o usuário de recursos hídricos estabelecem

${ }^{49}$ O texto completo da Resolução n⿳o 662/2010 da ANA encontra-se disponível em: $<$ http://arquivos.ana.gov.br/resolucoes/2010/662-2010.pdf $>$. Acesso em: 14 de julho de 2017. 
obrigações a serem executadas pelo usuário e prazos necessários para a correção de irregularidades" (art. 16).

Cabe ao usuário solicitar a celebração do PC, o qual deve conter, entre outros elementos, as obrigações a serem executadas para a correção das irregularidades e o cronograma físico de execução das atividades. Já a sinalização de intenção de assinatura do PC é suficiente para interromper a exigibilidade de multa diária (art. 16, §2º). O PC é apresentado pela Superintendência de Outorga e Fiscalização e precisa ser aprovado pela Diretoria Colegiada da ANA, que avaliará a "necessidade de celebração de PC para regularização do uso de recursos hídricos, a eficácia das ações propostas e a adequação dos prazos para execução, cabendo-lhe a discricionariedade de deferir o pedido, bem como alterar as ações e prazos apresentados" (art. 17, § $2^{\circ}$ ).

O Protocolo de Compromisso difere do TAC por ser válido somente se não houver procedimento administrativo ou investigação em curso, não constituindo, por óbvio, causa suspensiva para processo administrativo.

\section{Agência Nacional do Petróleo, Gás Natural e Biocombustível}

A Agência Nacional do Petróleo, Gás Natural e Biocombustível não prevê o TAC como um acordo substitutivo/suspensivo de procedimento administrativo. A Resolução no 53/2011 previa, no entanto, instrumento denominado Medida Reparadora de Conduta (MRC), entendida como "ação em que o agente econômico repara o não atendimento a dispositivo da legislação aplicável, em prazo pré-estabelecido, e passa a cumpri-lo em sua integralidade evitando a aplicação de penalidades" (art. 2, I). Essa resolução foi substituída, em 2012, pela Resolução no 32/2012, que manteve a essência do instrumento. A MRC tem escopo limitado, referindo-se, apenas à aplicação e cumprimento da Lei no 9.847/1999, que trata da fiscalização das atividades relativas ao abastecimento nacional de combustíveis, e do Decreto no 2.953/1999. A MRC pode ser proposta em resposta a uma ação de fiscalização da ANP, mas não na fase de investigação para instruir procedimentos administrativos. Logo, a ANP não celebra acordos substitutivos ou suspensivos quando instaurado procedimentos administrativos, mas possui remédio em período préinstauração. 


\section{CONCLUSÃo}

Os dados referentes à aplicação de multas e de arrecadação, apresentados na introdução, contam apenas parte da história. Por exemplo, entre 2000 e 2016, a ANATEL constituiu cerca de 60 mil multas, para um total de 5,2 bilhões de reais. Destes, foram arrecadados apenas 727,3 milhões de reais ou 13,9\% do valor constituído. Partindo desses dados, pareceria lógico incentivar a celebração de TACs, afinal a aplicação de multas não está (i) gerando efeitos dissuasórios, já que os agentes infratores têm demonstrada capacidade de evitar o pagamento das multas pela judicialização ${ }^{50}$, principalmente, sem sofrer as consequências legais do inadimplemento ${ }^{51}$, nem (ii) gerando receitas que podem ser revertidas como investimentos pela agência reguladora.

De fato, existem diversos TACs em negociação no âmbito da ANATEL - 37 pedidos, até dezembro de 2016, abrangendo processos administrativos que totalizam 9,1 bilhões de reais. Mais reflexão se mostra necessária, entretanto, sobre o desenho institucional e regulatório a ser aplicado quando da celebração de TACs. Isso fica claro a partir do relatório do TCU que apresentou extensivas críticas ao processo empregado pela ANATEL na celebração de TACs. Entre as principais críticas, notam-se a deficiência no processo de fiscalização do cumprimento de termos daqueles acordos, déficits informacionais no processo decisório, falta de transparência, sobreposição de competências gerando atrasos, entre outras. ${ }^{52}$

Esse breve exemplo deve servir de lição. Simplesmente prever a possibilidade de celebração de TACs não é suficiente. A gama de

\footnotetext{
$5045,1 \%$ do montante constituído encontra-se com pagamento suspenso judicialmente. Esse valor corresponde a apenas 1,5\% das multas constituídas. A própria ANATEL reconhece que essa proporção se deve ao fato de que as maiores empresas, que sofrem as multas com valores mais altos, têm capacidade de recorrer ao Judiciário. ANATEL.

Relatório Anual 2016. Disponível em:

$<$ http://www.anatel.gov.br/Portal/verificaDocumentos/documento.asp?numeroPublica $\underline{\mathrm{cao}=347175 \& \text { assuntoPublicacao }=\text { null \&caminhoRel }=\text { null \&filtro }=1 \& \text { documentoPath }=347}$ 175.pdf $>$. Acesso em: 15 de julho de 2017.

${ }^{51}$ Como, por exemplo, a incapacidade de obter certidão negativa de débitos, necessária para participar de licitações, e o impedimento para participar do licenciamento de novas estações.

52 TCU. Processo no TC 022.280/2016-2. Disponível em: $<$ http://www.telesintese.com.br/wp-content/uploads/2017/05/TAC-TELEFONICATCU-1.pdf $>$. Acesso em: 17 de julho de 2017.
} 
considerações relevantes sobre esse instrumento não pode ser subestimada. Precisão e segurança jurídica são elementos essenciais para que agentes fiscalizados considerem viável e vantajoso celebrar acordos com a administração pública. A disposição derivada do consensualismo emergente não se basta sem a demonstrável e demonstrada comprovação de que agentes públicos estabeleceram um ambiente seguro para negociações e, principalmente, para o período de execução dos termos do acordo. De outro lado, a eficácia do processo de fiscalização é fundamental à consecução dos objetivos de política pública pretendidos, tanto por garantir que eventuais infrações serão detectadas, servindo de instrumento dissuasório, quanto para garantir o acompanhamento do cumprimento dos TACs celebrados.

A pesquisa quantitativa realizada aponta para novas avenidas de inquérito. ${ }^{53}$ Analisar qualitativamente os TACs celebrados pelas diferentes agências reguladoras permitirá, por exemplo, compreender dinâmicas particulares que cada construção normativa produziu, sendo ainda particularmente importante, para essa finalidade, avaliar os requerimentos de TACs rejeitados pelos agentes e órgãos responsáveis pela sua celebração. A complexidade da matéria, evidenciada ao longo do presente artigo, contradiz a maneira episódica com que é tratada com frequência. A título de exemplo, a Medida Provisória no $780 / 2017^{54}$ institui o Programa de Regularização de Débitos (PRD) não-tributários junto às autarquias e fundações públicas federais. Trata, portanto, exatamente do regime de pagamento das multas impostas por agências reguladoras, oferecendo substanciais descontos (de até $90 \%$ ) a devedores que aderirem ao PRD. ${ }^{55}$ Ao invés de constituir instrumento para resolver o grave problema de arrecadação de multas administrativas, apontada pelo TCU, trata-se de instrumento destinado a aumentar a arrecadação do governo

${ }^{53}$ Ainda que tenha sido prejudicada pelas deficiências das agências reguladoras no cumprimento da Lei de Acesso à Informação. A ANEEL não forneceu qualquer informação, fazendo com que apenas os dados referentes a uma Superintendências fossem considerados por estes terem sido publicados previamente. Já a ANTAQ forneceu dados apenas a partir de 2014.

${ }^{54} \mathrm{O}$ texto completo da Medida Provisória no 780/2017 e demais informações relativas à sua tramitação se encontram disponíveis em:

$<$ http://www25.senado.leg.br/web/atividade/materias/-/materia/129244>. Acesso em: 17 de julho de 2017.

${ }_{55}$ No âmbito do processo legislativo que discute a MP no 780/2017, também foi sugerida emenda que trata de forma pontual e inespecífica dos TACs - Emenda no 23, da Deputada Gorete Pereira (PR-CE). 
federal em momento de crise econômica. ${ }^{56}$ Representa, possivelmente, incentivo ao não-pagamento das multas impostas pelas agências reguladoras. Não é outra a razão de agências, como a ANEEL, terem requerido sua exclusão do PRD. ${ }^{57}$

Como ficou evidente, existe grande variação entre a política de TACs nas agências reguladoras de infraestrutura brasileira. Enquanto algumas (ANTT e ANTAQ) empregam esse instrumento com alguma regularidade, ainda que em números modestos, outras (ANAC e ANATEL) celebraram pouquíssimos TACs desde a sua instituição como alternativa regulatória. Além disso, há aquelas, como a ANA e a ANP, que não tem sequer o instituto do TAC em seus regulamentos, assim como a ANEEL que o extirpou de suas normas internas após experiência considerada negativa.

Ainda assim, acredita-se que as lições podem ser compartilhadas. De forma semelhante, a experiência do CADE demonstra que o processo evolutivo pelo qual passa um instrumento de política regulatória como os TACs não pode ser interrompido ou manejado para resolver interesses pontuais ou conjunturais. A preocupação com a segurança jurídica e a previsibilidade, demonstrada pelo CADE, principalmente a partir de 2013, representa um importante diferencial em relação às agências

${ }^{56}$ De acordo com o Secretário-adjunto da Secretaria de Planejamento e Assuntos Econômicos do Ministério do Planejamento, Júlio Alexandre Menezes da Silva, "a Medida Provisória foi elaborada com esse espírito de aumento da receita do governo para reduzir o contingenciamento de despesa". AGÊNCIA CÂMARA. Agências reguladoras divergem sobre MP que parcela multas; ANEEL pede para ser excluída do texto. Brasília, 11 jul. 2017. Disponível em:

$<$ http://www2.camara.leg.br/camaranoticias/noticias/ECONOMIA/537809AGENCIAS-REGULADORAS-DIVERGEM-SOBRE-MP-QUE-PARCELA-MULTASANEEL-PEDE-PARA-SER-EXCLUIDA-DO-TEXTO.html>. Acesso em: 17 de julho de 2017.

${ }^{57}$ O Superintendente de Gestão Tarifária da ANEEL, Davi Antunes Lima, indicou que a MP geraria um sinal regulatório equivocado para as concessionárias e que "quando você permite o parcelamento dessas multas, você reduz os incentivos, e as empresas poderão preferir ferir as condições contratadas e piorar o serviço". AGÊNCIA CÂMARA. Agências reguladoras divergem sobre MP que parcela multas; ANEEL pede para ser excluída do texto. Brasília, 11 jul. 2017. Disponível em: $<$ http://www2.camara.leg.br/camaranoticias/noticias/ECONOMIA/537809AGENCIAS-REGULADORAS-DIVERGEM-SOBRE-MP-QUE-PARCELA-MULTASANEEL-PEDE-PARA-SER-EXCLUIDA-DO-TEXTO.html>. Acesso em: 17 de julho de 2017. 
reguladoras estudadas. De fato, a prescrição de que os TACs representariam uma "harmonização de interesses por meio do qual se substitui o incerto pelo certo" 58 não pode ser tomada a valor de face.

Pelo contrário, como ficou claro, a existência de níveis variados de discricionariedade, imprecisão e incerteza no processo de celebração de TACs no âmbito das agências reguladoras de infraestrutura produz um ambiente incerto em que os agentes regulados não têm interesse de navegar. Preferem a esfera judicial, onde as possibilidades de prolongar e postergar o pagamento de multas são inúmeras, especialmente para aqueles de grande porte e amplos recursos financeiros. Assim, fica evidente que a funcionalidade e eficácia dos TACs como instrumento para reduzir a judicialização das demandas na área de infraestrutura depende de um desenho institucional e normativo preciso e detalhado que os tornem efetivamente mais atraentes aos agentes regulados.

\section{REFERÊNCIAS}

ALMEIDA, Fernando Dias Menezes de. Mecanismos de Consenso no Direito Administrativo. In: Alexandre Santos de Aragão; Floriano de Azevedo Marques Neto. (Orgs.). Direito Administrativo e seus Novos Paradigmas. Belo Horizonte, MG: Editora Fórum, 2008

ARAGÃO, Alexandre. A Consensualidade no Direito Administrativo: Acordos Regulatórios e Contratos Administrativos. Revista de Informação Legislativa, Vol. 42, 167, 2005.

ANATEL. Relatório Anual 2016. Disponível em: $<$ http://www.anatel.gov.br/Portal/verificaDocumentos/documento.asp? numeroPublicacao $=347175 \&$ assuntoPublicacao $=$ null\&caminhoRel $=$ null \& filtro=1\&documentoPath=347175.pdf $>$. Acesso em: 15 de julho de 2017.

${ }^{58}$ SADDY, André; GRECO, Rodrigo. Termo de Ajustamento de Conduta em Procedimentos Sancionatórios Regulatórios. Revista de Informação Legislativa, Vol. 52, 206, 2015, p. 183. 
AGÊNCIA CÂMARA. Agências reguladoras divergem sobre MP que parcela multas; ANEEL pede para ser excluída do texto. Brasília, 11 jul. 2017. Disponível em:

$<\underline{\text { http://www2.camara.leg.br/camaranoticias/noticias/ECONOMIA/53780 }}$

9-AGENCIAS-REGULADORAS-DIVERGEM-SOBRE-MP-QUEPARCELA-MULTAS-ANEEL-PEDE-PARA-SER-EXCLUIDA-DOTEXTO.html>. Acesso em: 17 de julho de 2017.

BELLOUBET-FRIER, Nicole; TIMSIT, Gérard. L'administration en Chantiers. Revue du Droit Public et de la Science Politique en France et a l'Étranger, Paris, No. 2, 1994.

\section{CONSELHO ADMINISTRATIVO DE DEFESA ECONÔMICA. Guia}

Termo de Compromisso de Cessação para casos de cartel. Brasília, 2016. Disponível em: $<$ http://www.cade.gov.br/acesso-ainformacao/publicacoes-institucionais/guias do Cade/guia-tcc-versaofinal.pdf $>$. Acesso em: 10 de julho de 2017.

. Balanço 2016. Brasília, 2017. Disponível em:

$<$ http://www.cade.gov.br/servicos/imprensa/balancos-eapresentacoes/apresentacao-balanco-2016.pdf/view>. Acesso em: $17 \mathrm{de}$ julho de 2017.

CARNEIRO FILHO, Humberto João. Estrutura, Funcionamento e Evolução do Fundo de Defesa dos Direitos Difusos. Revista Jurídica da Seção Judiciária de Pernambuco, No. 3, 2010.

DALLARI, Adílson. Viabilidade da Transação entre o Poder Público e o Particular. Interesse Público, Vol. 4, 13, 2002.

MARQUES NETO, Floriano de Azevedo; CYMBALISTA, Tatiana Matiello. Os Acordos Substitutivos do Procedimento Sancionatório e da Sanção. Revista Brasileira de Direito Público - RBDP, Vol. 8, 31, 2010. 
MOREIRA NETO, Diogo de Figueiredo. Novas Tendências da Democracia: Consenso e Direito Público na virada do Século - o caso brasileiro. Revista Eletrônica sobre a reforma do Estado, No. 13, 2008.

. Novos Institutos Consensuais da Ação Administrativa. Revista de Direito Administrativo, No. 231, 2003.

PEREIRA, Guilherme Teixeira. Política de Combate a Cartel no Brasil: Análise Jurídica do Acordo de Leniência e do Termo de Compromisso de Cessação de Prática. Dissertação (Mestrado em Direito e Desenvolvimento Econômico e Social) - Escola de Direito de São Paulo, Fundação Getulio Vargas, São Paulo, 2011.

POPPER, Andrew. An Administrative Law Perspective on Consensual Decisionmaking. Administrative Law Review, v. 35, 3, 1983.

SADDY, André; GRECO, Rodrigo. Termo de Ajustamento de Conduta em Procedimentos Sancionatórios Regulatórios. Revista de Informação Legislativa, Vol. 52, 206, 2015.

SUNDFELD, Carlos Ari; CÂMARA, Jacinto. Acordos Substitutivos nas Sanções Regulatórias. Revista de Direito Público da Economia - RDPE, Vol. 9, 34, 2011

TRIBUNAL DE CONTAS DA UNIÃO. Relatório e Parecer Prévio sobre as Contas do Governo da República - Exercício 2013, p. 95. Disponível em:

$<$ http://portal.tcu.gov.br/tcu/paginas/contas governo/contas 2013/docs/ Relat\%C3\%B3rio.pdf $>$. Acesso em: 17 de julho de 2017. 
Regulação Consensual: a experiência das agências reguladoras de infraestrutura com termos de ajustamento de conduta Consensual Regulation: the experience of the regulatory agencies on infrastructure with the conduct adjustment commitments Submetido em: 2017-07-31 Aceito em: 2017-07-29 